\title{
CHILD AND PSYCHOLOGICAL ASPECTS OF A DOLL (Theoretical approach)
}

\author{
Jasna Gržinić, PhD \\ Department of Preschool and Primary Education \\ "Juraj Dobrila" University in Pula (Croatia) \\ e-mail: jasna_grzinic@inet.hr \\ Saša Ilić, graduating student of preschool teaching \\ Department of Preschool and Primary Education \\ "Juraj Dobrila" University in Pula (Croatia) \\ e-mail: sasa.ilic@yahoo.com \\ Karmen Vidović, graduating student of preschool teaching \\ Department of Preschool and Primary Education \\ "Juraj Dobrila" University in Pula (Croatia) \\ e-mail: karmen_vidovic@net.hr
}

\begin{abstract}
$S \boldsymbol{u} \boldsymbol{m} \boldsymbol{m} \boldsymbol{a} \boldsymbol{r} \boldsymbol{y}$
This work is about the search for the lost meaning of a doll in the context of busy and chaotic world which is being represented by the laws of economic income. In these context are being questioned the ranges of philosophy, psychology, psychoanalysis, pedagogy and literature. They all indicate the need for syncretistic thinking about the world and the importance of a doll (puppet) and puppetry art.
\end{abstract}

Key words: a doll (a puppet), psychoanalysis, playing, therapy, upbringing

"Dolls serve to us as talismans. Talismans are reminders of what we feel, but do not see, of something that is as it is, but we cannot see it immediately. Talismanic numen of a doll is here to remind us, to speak and to anticipate for us."

(Estes, 2004, 107)

What is a doll? What does it mean to a man? Which are the layers of meaning kept in its long history? These are only few of the questions that derived from onesemester meetings with the students of preschool teaching at the Departement of Preschool and Primary Education in Pula. From the conventional corpora of the 
knowledge about puppetry, a doll has discovered during lectures and meetings with full -time and part-time students, richness of its meanings, which facets are especially important in the context of actual specific world and social situation. However, it has been showed that thinking about a doll, means, besides others, taking into account psychological, sociological and philosophical ranges which are all known companions to pedagogy as such; dealing with a doll means allowing yourself and others deeper insight into the secrets of human ego, whose enigma shows itself as puzzling and unreachable as the society lulls itself, publicly and declaratively, into its own almightiness.

\section{A doll and a child - why and how}

The importance of a doll in a child's growth was emphasized a million times. It was proved that each of different forms of interaction with a doll gives possibilities for better understanding of a child, restoring closer relationship, or even the change of the relationship with a child. In the child itself, however, she stimulates tolerance, emotional intelligence and empathy, develops richness of metaphoric thinking and expression, the growth of imagination and creativity (Pokrivka, 1985: 23; Hug and Renfro according to Hicela, 2006: 12, 20; Hug and Renfro according to Vidić, 2006: 25).

Therefore, it is shown to be of extreme importance one, maybe not sufficiently emphasized and, at first glance, minor fact that a doll does not want and must not be man's replica because of the world it creates, which is the miraculous world of imagination and the man that it stands for is an imaginary man (Mejerholjd, 1976: 117). Thanks to that specific power of a doll, she even today, especially today, becomes such a necessary media that can lead us out of the 'real' world to the dimensions of the true personality which is being ignored as a consequence of specific different life rhythms' tempos. These parameters have an interest only in economic profit, and, therefore, with quick earnings as superficiality in general, cause perpetual shuttering of the imagination worlds and man's structure. Therefore, he must be able to solve his psychological difficulties as fast as possible and, of course, as cheaper as possible. But, a doll stays always here, and modern generations can, even in the form of computer games and commercial characters, foresee its power which Clarissa Pinkola Estes calls Symbolic treasure of instinctive nature. In archetypical thinking of the story about Vasilisa, Estes sees a doll as a vidacita, a little instinctive life power which is impetuous and permanent. No matter what trouble we are in, she experiences life hidden inside ourselves.A doll is a symbolic homunculus, little life, the symbol of that numinous which lies buried deep in all people, small and incandesced facsimile of the original self. She is connected with the symbols of elves, evil spirits, fairies and dwarfs. In the fairytales they, as tireless beings who skilfully continue inner work, represent low droning of wisdom inside cultural psyche. They work even when we sleep, especially then, and even when we are not fully aware of what we are implementing. In the context of female principle (via archetypical theory C.G. Jung), Estes's doll is being observed as our inner female spirit, as the voice of inner reason and inner 
consciousness. She is the one who reveals hidden enemy and what to do regarding it (Estes, 2004: 104, 105). Therefore if the doll arose out of the world of revelation, and within it creation, she would represent our creatio, which always and unmistakeably comes from the world of play/playing, the world of such an unusual importance in the life of the human individual.

\section{Play, doll, symbol}

In a play we show our real Self, discover our difficulties and at the same time overcome them or we are, with the help of her symbolic power, "maintaining" ourselves despite the inauspicious circumstances. Hence it is not strange that a psychotherapist Zlatko Bastašić will already in the first chapter of his famous book Lutka ima srce $i$ pamet $^{1}$, conclude that the cause of social pathologies such as drug addiction or delinquency lies in the lack of the place to play or the minimal space for playing (Bastašić, 1988: 5). A philosopher Martha Nussbaum² in her thoughts about the laws of modern economy, devastating results in the field of the world's social picture and the power of human empathy, points out how a play and entertainment are not just simple attachments or supplements to human life, but they illustrate how central elements of life are to be observed on an effective way. To learn how to fancy/imagine in traditional economy and in the context of utilitarian mind meant doing something useless because facts are what we need, and what use has anyone ever had from a man on the Moon! Nussbaum concludes: a child that looks forward to reading stories and lullabies starts to understand that not everything in human life is of some use. It is learning the way how to be able to get involved in the world and that, by doing so, it is not only focused on the idea of usefulness, but also being able to rejoice for the things because of themselves alone. And precisely that ability a child accepts through its relations with other people (2005: 68-69). David Winnicott differentiates the aspect of play from the gerund playing: play is what is universal and belongs to health, and playing contributes growth and therefore health, which leads to group relations and can be a way of communication in psychotherapy. Since psychoanalysis has developed as highly specialized way of playing for the purpose of communicating with self and others, Winnicott emphasises that it is useful to remind every analyst not only of what he or she

\footnotetext{
${ }^{1}$ Op.p transl. A doll has heart and brain

${ }^{2}$ Besides economic utilitarianism which includes numerical indicators and statistic balance sheets, Martha Nussbaum successfully emphasises the importance of literal imagination, by which she implicates all deeper layers of imagination sui generis, as potential which can significantly contribute to our public, and consequently personal life. Such imagination/fancy that is being realised not only in the field of literature, implicates stimulating kinds of emotions and thinking, hence ability (particularly for a child) to give some form a life. Thus makes such imagination morally valuable. Namely it is about the ability that what we have built in imagination is being observed as something which is by itself good and expresses joy. It is of importance to say that Nussbaum based her work on the assumptions of famous economist, at that time a head of the world's monetary organisation Amarty Sena as well as on their joint exploration in the field of the quality of life $(2005: 69,170)$.
} 
owns to Freud but also of what owns to natural universal thing called playing (2004: $60) .^{3}$

To create opportunities for children to be able to play is by itself psychotherapy which has direct and universal application and includes creating society's positive thinking towards playing. Especially interesting is Winnicott's conclusion according to which playing is always an experience, creative experience in spatiotemporal continuum or namely, basic form of living, because it represents searching for oneself. That search asks for conditions that can relate to creativity, and in playing but only in playing, a child or a grown-up is able to be creative and to commit its complete personality, even to discover in fullness itself alone (same: 69, 74). This author emphasises the importance of an ability to play what each child has: if the child is playing, there can appear one or two symptoms, but when it is able to enjoy in a play alone or with other child, then there is no need to worry about any severe distress. If it is expressing rich imagination in the play and if with it comes enjoyment in games that are based on the exact observing of the outer world, then parents can be completely happy, even if that child wets in the bed, stutters and shows attacks of anger or if it repeatedly suffers from cramps or depression. Hence, the way the child plays shows that it is, in averagely good and stable surroundings, able to develop personal way of living and finally, become a complete human being the world around it expects and waits for with arms wide open (1980: 141)

A play with a doll is impregnated with layers whose realisations act simultaneously, in a nutshell. Even when it is only playing or just watching an animator with a doll, a child knows that everything is "such as". When a child does not understand this process, this indicates deeper signs of depersonalisation or more complex psychological disorders (Bastašić, 1988: 9). It is about the ability of symbolisation which is, according to Melanie Klein, a confirmation that there are no serious disorders within a child (1983: 24). In his work Bastašić has discovered in a doll something magical, animistic, just as it happens in early childhood, when things have soul and else what we have intended for them. By discovering such new adventure of puppetry, Bastašić emphasises, a doll had helped him in realisation his own therapeutic identity (1988: 9).

In psychotherapy with a doll, the elementary procedure consists of a part where a child plays something with dolls or chooses dolls by which it will create a story. ${ }^{4} \mathrm{~A}$

\footnotetext{
${ }^{3}$ Winnicott will in the context of newer neglecting of psychoanalysis say: 'I am into unconscious motivation, data that I need cannot be found out from questioners. Computer cannot be programmed to serve unconscious motives of individual, experiment rabbits for testing. And now, the ones who have spent their lifetime dealing with psychoanalysis have to desperately call for common sense against crazy belief in superficial phenomena which characterised computer tests of human beings.' (2004: 175)

${ }^{4}$ Compare 'We always tell stories about ourselves. When we tell them to others it could be said we perform direct storytelling actions. By saying, however, that we are speaking also to ourselves, we incorporate one story into the other. From this perspective "selfness" is storytelling... besides that, we always tell stories about others... we are telling others just as we are storytelling selves. Therefore telling to others stories about self is double storytelling." (Roy Schafer, "Narration in the Psychoanalytic Dialogue' p 218, gouted according to Felman 1992: 258)
} 
reason for that is the fact, according to which, playing means alleviating. Relaxing in the sense of free association means that the patient on the sofa, or a child on the floor surrounded with toys, must be allowed putting forward a sequence of ideas, thoughts, impulses, unconnected sensations, besides on neurological or physiological way, which after all, is not graspable. This means: where there is a purpose, or anxiety, or there is a lack of trust based on a need for defence, analyst will be able to recognize and emphasise the relation (or several relations) between different components that make the content of free association (Winnicott, 2004: 76).

Hence, for example, D.Winnicott during the third consultation in the therapy with a little girl named Piggle finds this little girl in the waiting room with her "baby" who was, in fact, a little doll with a diaper and a safety needle. She calls her doll Gaddy-gaddy-gaddy (from Gabrielle, baby-baby, Galli-galli-galli). Throughout her therapy that baby (doll) gave Piggle the ability to identify herself as her mother - self. During the meeting Piggle has a doll-glove and asks from the therapist to make it ashamed so she can hit it. During the analysis Piggle also has a big doll Francis (Winnicot, 1997: 37, 40, 42, 43, 92).

It is indicated that a doll is, as a matter of fact, the perfect object, and an objectification itself which is being rooted in the models of nurseling behaviour in the use of the first non-I possessions. That child's activity begins with a newborn's placing of a fist in the mouth and then, after the phase of "transferable phenomena"s (part of a sheet or a blanket a child puts into mouth with fingers and similar) gradually comes to close connecting with a teddy, a doll, or some other firmer or soft toy. Boys are more inclined to move to the firmer toys, while girls incline towards "creating a family". However, it is of importance to emphasise that there is no marked difference between boys and girls in the use of the non-I possession, meaning transferable objects or symbols. This first ownership is being used in relation with special techniques that have one's origin from the earliest nurseling time and contain autoerotic activities or exist independently from them. The first transferable object is of greater importance than a mother, almost inseparable from a child. However, it must be said that it is not about the fact that the object itself is transferable. The object itself represents nurseling's transfer from the state in which he is unified with a mother in the state where she is something outer and separated. (Winnicott, 2004: 18, 19, 22, 30; 1980: 186). The nurseling's trust in mother's reliance, and therefore in the reliance of other people and things, enables the separation of I and non-I. At the same time, it could be said that the separation was avoided by refilling of potential space (between the mother and a child) with creative

\footnotetext{
${ }^{5}$ Winnicott introduces terms "transferabke objects" and "transferable phenomena" to indicate special area of experience between a tomb and a teddy, between oral erotics and true objective relation, between primeral creative acitvity and the projection of what had already been imprinted into the counsciousness, between the first lack of counsciousness and admittance of that feeling ("Say 'ta"'). Hence babbling of a nurseling, as well as the way an older nurseling goes through the repertoar of songs and melodies while being prepared to go to sleep, fit into so called intermedial area in the capacity of transferable fenomena together with the use of objects that are not part of the child's body, but a child still does not understand they don't belong to the outer reality. He is interested firstly into the first possession, as well as a intermedial area between subjective and one that is perceived as objective.
} 
playing, by using symbols and everything else what at the end contributes to cultural life (same: 71, 137).

As speech is to adults in psychotherapy, so is playing to children (Anna Freud 2002: 9) and especially playing with a doll. The richness of a fairytale is confirmed even in this aspect so the children in therapeutic game often play fairytale and stories. For them human values such as love or friendship are particularly inherent, but evil forces also threaten to destroy good (Bastašić, 1988: 19; Bettelheim, 2000: 16-26). The dolls are immanent to fairytales because they are like fairytale's heroes, named with only one or two adjectives, limited in their meaning, brought down to a symbol. The characters in a fairytales, as in the play with a doll, are defined by their function in the action. Russian folklorist Vladimir Jakovljevič Propp mentions 31 function of the characters in the analysis of Russian fairytales, which come immediately after a starting situation in the fairytale. Propp puts forward in the fairytale a hero and his opponent and out of their relations derive different types of functions, such as, for example, hero's breaking a ban after opponent's (enemy's) expressing of a prohibition (Propp, 1982: 3371). That explicitness of individual dolls' meanings, brought down to general symbols, makes it easy for a child to play. Thus a fairytale enables working through the transfer presented in the given roles and the analysis of the content (Bastašić, 1988: 20-21) because every fairytale is a magical mirror that reflects some expressions of our inner world and steps which are necessary for growth from immaturity to maturity (Bettelheim, 2000: 265).

The presented insights into the relations between a doll and human psyche are the results of a long-lasting research in the field of human psyche. These are based on Sigmund Freud's work (1979), in psychoanalysis. It is especially relevant for the discovery of subconscious, preconscious, conscious and over-conscious. Basic constituent elements of psychoanalytic studies are studying about resistance and suppression, about unconscious and etiological meaning of sexual life and about the importance of the experience in childhood (Freud, 1979: 42). Total psychodynamic and especially psychoanalysis in its theoretical and practical dimension, is a part of metacommunication "Where unconscious, must be conscious" - is the basic element of psychoanalytic treatment. In other words, the analyst searches for the "true" message of the sick person's self. Freud's determinism is convinced that for every, apparently nonunderstandable behaviour, exists unconscious cause. Conflict is a clash of, mainly unconscious motifs; it is the visible, often illogical consequence of intra-structural conflicts. The main reasons for communicational "noises" are resistances to change, precisely in spiritual development (Gruden, 1996: 21).

\footnotetext{
${ }^{6}$ Meta-communication is transmission of information within visible communication. Each communication is a symbol, a code and a true experience of a message is, in no case, communicational content experienced as such by secondary thinkable process. In the medicine therapy metacommunication is a base for treatment. In the contact with a sick person, a doctor always searches for that "behind". The knowledge of psychoanalysis and emphatic capabilities are of help for metacommunicational decoding. The truth in meta-communicational message is that all communicational models are a play (Gruden, 1996: 23).
} 
The works of Anna Freud (2002), then Melanie Klein (1983) and David Winnicott $(1980,1997,2004)$ show the importance of psychoanalysis with children. Anna Freud will, in that content, conclude how child's neurosis is (as well as with others) inner given thing and it also is defined by the three powers - instinctive life, Ego and Super-Ego. The same is with the outer world, as such unfavourable for the analysis but organically important factor that goes back deep into the child's inner relations. Therefore the major part of the sickness cannot be prescribed to a child only, but mostly to its surroundings, and by describing situation of transfer, it was shown that the analyst is forced to share, with the given objects, missing child's feelings of hate and love. A child analysis is not a private thing, which is being played between two persons, analyst and its patient. A child's Super-Ego hasn't yet become a public presenter of requests taken from surroundings, so it is still organically dependant on that surroundings. These objects, taken from the surroundings, have an important role in self-analysis, especially in its final part during which his instincts are being liberated. With a grown-up neurotic person we must only count on his instinctive life, his Ego and his Super-Ego, and we don't have to torture ourselves with the destiny of the ways of his unconsciousness. It falls under the influence of Super-Ego, which takes responsibility for its further realisation. Freud is asking herself to whom to relinquish the decision making in the child analysis. To a child's raiser, with whom child's Super-Ego is so inseparably connected, hence in most cases, to its parents. ${ }^{7}$ In this sense, the analyst must also succeed in putting himself, for the purpose of success in analysis, in the place of the child's Ego-ideal, and cannot start his analytic work before he is sure that he is able to control a child in every aspect: he must control and raise (2002: 75-83).

Since it was discovered an application of psychoanalysis on children in general, through the therapy with playing, a doll is seen as a very significant element and it is like that even today. When, in the context of psychotherapy, children start to play with a doll, the material often becomes preconscious and it is possible, by modifying a game, to bring it nearer to conscious. In correlation with other toys, dolls express more directly either anger or love towards the objects, because games with dolls are often stimulated with real events and even traumatic experiences (Bastašić, 1988: 41, 45). Hence, for example, when Anna Freud mentions two means that are in disposal for a real analytic work with a child - explaining dreams and dreaming in reality, she also speaks about a girl who in concrete struggle against her younger brother, dreams while awake: '...better not to come to world, better to die. I imagine I have died and that I come again in the world, as an animal or a doll. As a doll I know to whom I would belong, to a little girl that my nanny was earlier with, she is actually good...' (A.Freud, 2002: 53-57)

The conclusions of Melanie Klein contribute to psychoanalytical theory in total and are arising from the technique of playing that she developed in her work with little

7 Compare with "As a universal model, a family is an unbreakable entity, with a concrete realisation of family structures, hence the structure of relation and directs origin. As the source of normality, it is also, and we know it thanks to psychoanalysis, a cause for all forms of psychic pathologies: psychosis, perversion, neurosis and so on." (Roudinesco, 2005: 109). About specification of child's Super-Ego see S.Freud, 1979: 253. 
children. Until then, psychoanalysis had been considered suitable for children only after the latent period. Klein mentions the most suitable toys for psychoanalytic game of playing: wooden figures of men and women, usually in two sizes, cars, wheel-barrow, a swing, a railway, planes, animals, trees, cubes, houses, fences, a paper, scissors, a knife, pencils, chalk or colours, balls and marbles, modelling clay and a rope (1983: 11, note. 5). Numerousness and diversity of small toys enable child to express wide range of fantasies and experiences, but it is important that they are not mechanic and that human figures differ only in colour and size, without the marks of any particular occupation. That simplicity makes it possible for a child to use them in different situations (same: 11, 12). This especially refers to small cubes, dolls and cars, which do not only represent things that interest a child, but in the play they take various symbolic meanings, which are related to child's fantasies, wishes and experiences. The analysis of a play has shown how symbols make it possible for a child to transfer to non-living objects not only its interests, but also fantasies, anxieties or guilt. In that way, a child experiences tremendous relief through the play which is one of the reasons why the play is so important to a child (same: 23 ).

The beginning of such practice is the case of a five-year-old boy named "Fritz" who has been expressing, from the very beginning, his fantasies and anxieties mainly by playing with toys in his home. An additional material had appeared by the systematic explaining of his play from the analyst - in accordance with basic psychoanalysis principle - through free association. Klein also emphasises her second principle - that was established by Freud, and which she from the very beginning considered as a ground principle: exploring of unconscious through psychoanalytic procedure as a main task, which is achieved by the analysis of transfer (same: 7-9). From her work, it is also famous the case of a girl Rita, who was showing anxiety through her inhibition while playing, which was mainly reduced to putting on and off doll's clothes. Klein soon enough comprehended girl's anxieties which were the reason for her obsessions and interprets them to her. This case had strengthened her belief that a precondition for psychoanalysis of a child is understanding and interpreting fantasies, feelings, anxieties and experiences that a child expresses in a play, or if it is being inhibited in a play, the cause for that inhibition (same: 9,10). The significance of a play is being confirmed also by the case of a seven-year-old girl from 1923. She did not like school and during the first sessions Klein couldn't managed to establish better contact with her. Klein went to her children's room, took a few toys, cars, little dolls, several cubes and a railway, put it in one box, and returned to the girl. She was not interested in drawing or some other activity, but little toys have attracted her attention and she immediately started playing with them. The analyst noticed that two dolls in a play represented a girl and one boy, her colleague from the class that she had previously heard about. It appeared to her that the behaviour of these two dolls was shrouded in some mystery, while the other dolls stood aside not to disturb them or just to observe. Two dolls continuously experienced accidents, were dropping or having car-crashes. While it was repeating, she noticed that the anxiety of a girl rose. Then she explained to a girl the details of her play which indicated that she and her friend had some kind of intercourse and that she got really scared it would become known. The analyst also said that she seemed so worried at one moment of a play that it appeared as she wanted to stop it. 
Klein also reminded the girl that she did not like school which could have been connected with her fear that a teacher would find out about her behaviour towards a boy and might have punished her. She discovers the little girl is mostly afraid of the mother and that is why she is so distrustful to her, and most probably she feels the same way towards the analyst. This explanation causes stunning consequences: girl's anxiety and distrust firstly reach the peek, but soon yield to obvious relief. Difficulties founded on deep anxieties were removed gradually in the course of long-term treatments. Her hate towards school became significantly lower and her interest for learning slowly grew (same: 11).

In the technique with a play Klein has realised the importance of the analysis of transfer. A patient in the transfer with the analyst repeats prior feelings and conflicts. So Peter, the boy, after the analyst explained that a toy he had demolished represented his brother, realised that he would never do that to his real brother, but only to his brother toy (same: 23, 24).

Basically, a patient can be given help if, by interpreting transfers, his fantasies and anxieties are returned in the childhood where they appeared firstly, in relation to his first objects, which are, as a matter of fact, mother's breasts, even within the children that were not breastfed. The relations with those objects, with which all aspects of our social life are related, start immediately after birth and are appearing with the first feeding. Klein explains the relevance of the process of separating good and bad toys, as well as the influence of such processes on the development of I, by recognising that in child's conscious mother firstly appears as a good and a bad breast, that are between themselves separated, and that in the time span of a few months these opposite characteristics start to connect in the unity parallel with bigger integration of I. Child's experience of the outer world, that very soon includes its ambivalent relation towards the father and other members of the family, is constantly exposed to the influences of the inner world which it builds and on which it has influence. And these inner and outer situations are always mutually related since introjections and projections act parallel from the very beginning of life (same: 24, 25). Precisely in the analysis with the girl Rita, mercilessness of her Super-I (super-ego) became a true surprise. She was usually playing strict and rough role of a mother who treated her child violently (mother was played by a doll or by the analyst). Rita's ambivalence towards her mother, a strong wish to be punished, feeling of guilt and nightmares, brought Klein to the realisation about efficiency of strict and relentless Super-I much earlier than Freud had assumed. The child of Super-I feels with something that acts in itself in a real way, and which in fact, consists of different forms built on its own experiences and fantasies and is created in a period when a child inner-rises (introjects) its parents (same: 18-19).

Child behaviour towards the toy it has demolished discovers many things. It often puts aside the toy that represents, for example, a brother, a sister or a parent, and for some time does not pay attention to it. By doing this, it shows hate towards the destroyed object, which is a consequence of fear that the attacked person (represented by a toy) will seek revenge and become dangerous. The feeling of being hunted may be so strong that it can cover feelings of guilt and depression, which also appear after committed damage. However, Klein concludes that one day a child will probably look for the destroyed toy in its drawer: this means that, in the meantime, the analysis of 
some important defences has succeeded and by that the feeling of hunting was diminished, enabling a child to experience feeling of guilt and an urge to undo the harm. At the same time, it is possible to notice a change in child's relation with its brother or sister represented by a toy in their relationships, generally. This change confirms reducing of anxiety caused by the feeling of hunting. This gives a chance to the sense of guilt and a wish to redeem damage, and feelings of love that were being jeopardized by exaggerated anxiety (same: 13-14).

The diversity of emotional situations which can be expressed in a play is almost unlimited: it can be expressed feelings of denial or rejection, jealousy on one of the parents, or brothers and sisters, aggression which follows jealousy, satisfaction because of the partner in a play or ally against parents, feelings of love and hate towards newborn child or the one being expected, as well as accompanying anxiety, guilt, and the urge to repair the damage. In child's game we often come across the repetition of real experiences and details from the real life, which are often interwoven with its fantasies. It is significant that sometimes in child's play and associations there are no present truly important events from their lives, but the accent is mostly put on the seemingly less significant events. However, these less significant events are very important for a child because they stirred its emotions and fantasies. Every action, such as scribbling on the paper or cutting, as well as every detail in behaviour, such as change in pose or face expression, may indicate what is happening in child's consciousness, and especially when they are combined with what the analyst had found out from parents about child's difficulties. Children understand in total interpretations if they relate to important details in the material. The analyst must give as concise and as clear interpretations as he can and by doing so, use child's way of expression. Even very little children have the ability to realize, which is sometimes even greater than within adults. This can be explained with the fact that the connection between consciousness and unconsciousness are stronger in little children than in adults, and suppressions are less strong in children than in adults. According to Klein, intellectual abilities of children are often underestimated and children sometimes understand more than is usually thought they do (same: 14-15).

Playing with dolls in psychotherapy will explain points of regression and fixation, a complex picture of psychical processes, and also confirm the thesis that a child very early embeds in self problems of its parents. They also enable transfer and projection of fantasies and feelings, facilitate facing fears, filling the empty space and prevent regression. They have an important role in bridging emptiness of separation, they make it possible for the magic animistic thought to start functioning, to overcome phase of mourning, forfeiting aggression and its treatment.

Referring to Klein's work, especially to the case of the boy Dick ${ }^{8}$, Jacques Lacan will point out the importance of analyst's inspiration for understanding and not

\footnotetext{
${ }^{8}$ The case is a about four-year old boy, who has, considering the poorness of his vocabulary and intellectual achievements, been on the level of 18-months-old child. He was, in a large amount deprived of affective stages and indifferent towards the presence of a mum or a nanny. He is sometimes demonstrating anxiety on abnormal level. He is not interested in almost anything; he is not 
interpreting, therefore reproaching Klein for analytic refusal of understanding and ultimate cruelty of sticking symbolism in a little boy. ${ }^{9}$ In the context of the myth about Oedipus, Lacan is asking himself about narrative-symbolic effect of the myth, for its productive practical and clinical effect (Felman, 1992: 266). On the question why is the story about Oedipus effective both in clinical experience and in literal, Lacan points out that it is important to ask oneself not what the story means, but what the story does. Dick has not got the ability of symbolisation; he is, according to Lacan, in complete brutal reality, unestablished reality and completely undifferentiated. Hence Shoshana Felman asks following questions: what makes a baby to accept - i.e. to adopt, make them its own, to seize - language words, i.e. the power of symbolisation? She finds the answer in Lacan's perception: symbolic - wish and power of symbolising - depends on fundamental need for naming: the need of communicating to other, the attempt to attract attention of the other towards something that is missing to someone who is naming, who is communicating (same: 1992: 269). Of course, it is perfectly clear here that such ability is being "learnt" in a play, and particularly in the play with a doll. By making toy-trains symbols, Lacan points out, Klein has acquired verbalisation, she had symbolised one efficacies relation, the relation of naming being with the other. She noticed - in other words, she enforced - symbolisation of the myth about Oedipus. Outside the sessions, the child's relations are developing on the level of Oedipus. A child symbolises the reality surrounding it out of this nucleus, this vibrating cell of symbolism that was acquired by Melanie Klein. This is what she will later name "opening the door to its unconscious".

The success of interpretation and its clinical efficiency does not come from the exactness of meaning, but from the way in which discourse of Other thinking puts a child into the language, in relation to people that are surrounding it and who are close to the child. In that sense Dick's recovering is a story about his development, his way from projection to introjections, from Imaginary to Symbolic, from the stage that precedes primary identification of "mirror image stage" to the stage of finalising secondary identification - through child's introjections of "father's name" and with that constitution of his super ego. Symbolic assumes differential placing of subject on the third position (the first is "inner", second "outer" and third "I-self"). It is a place from which dual relation is understood and also a place through which he is articulated and which turns a subject (as that exact third place) in a language marker in the system. With that, it is enabled to have symbolic relations to the other people and to articulate personal wishes, personal unconsciousness, unknown, meaning that what Lacan names as performative, and not cognitive, key. The success of this therapy is in effective producing of calls what were missing in child, addressing that later becomes its motivation in introjections of human discourse (language). By calling a boy "Dicklittle-train", naming him inside constellation and symbolic structure, Klein's speaking

playing and has no relations to surroundings. He was mostly producing sounds without the meaning. (According to Felman, 1992: 263-264)

${ }^{9}$ Compare: 'I took a big train and put it next to one smaller, called them "Daddy-train" and "Dick-train". He instantly took the train that I named "Dick" and drove it to the window saying:"Train stop!" I explained: 'A train stop is a mum; Dick is going to his mum." (Same: 1992: 264) 
action produces a call to Dick, performativly setting him as subject with help of a discourse (Lacan, The seminar, 98-100. according to Felman, 1992: 2701, 271, 274). ${ }^{10}$

Complex and even stiffer relations of a doll and psychoanalysis are maybe best shown in Lacan's conclusion about the purpose of the analysis:

The purpose of analysis is nothing else but - recognising what function the subject is taking in the order of symbolic relations that cover a complete filed of human relations, symbolic relations, which first station is Oedipus's complex that solves accepting of a gender. (The Seminar (book1) page 80, according to Felman, 1992: 276)

\section{In the search for a doll}

In search for unconscious, for the discourse of the Other, ex-centrical in the relation to the discourse of I-selves, it is enough to demonstrate metaphorical discourse of the Other. In this sense, there is a wish as a central function of total human experience, but it is not, by itself, also a wish for something nameable. And rightly psychoanalytic goal is, opposite to that, to teach a subject naming, articulating, enforcing the existence of a wish, which is, literally meaning, below existence. And precisely because it is about recognising something that was already there - given (Lacan, The seminar (book II) according to Felman, 1992: 298), it is of great importance the process by which we go to the other side of self, and which the oldest media- doll makes much more easier.

It is being questioned why is a doll so little present in all important aspects of communication with a child. Why does such small number of people use these effective therapeutic methods in the world that suffers under the pandemic of psychic illnesses?

The answer was offered by Elizabeth Roudinesco, calling attention to famous manuel diagnostique et statsitique des troubles mantaux (DSM), whose first version (DSM 1) was made in 1952 by American Psychiatric association (APA). That year, Manuel, was taking care of acquisitions of psychoanalysis and dynamic psychiatry. It was defending the idea that psychic and mental disorders are arising, in their essence, out of unconscious history of a subject, its place in the family and relations with social surroundings. In other words, it mixed the triple approach: cultural (or social), existential and pathological in correlation with the norm. In such perspective, the term of organic sample is not neglected, and psychopharmacology, in its full expansion, is being used combined with treating by words or other dynamic therapies. With the development of liberal approach in treatment that places clinic under the critic of profitability, Freud's thesis are considered to be "inefficient" in the therapeutic aspect:

\footnotetext{
${ }^{10}$ In this sense, Lacan concludes: 'But if the person to whom I speak to, I call by a name which I chose to give it, I am indicating subjective function which it will overtake when its turn to speak comes, even if it refuses to take this function(...) I speech search for echo-response-from the other. I am being established as a subject by my question. In order the other can recognise me, I express what was the only in the function of what will be. To find the other, I am calling it by name it must accept or refuse, in order to be able to respond." (Ecrits, according to Feldman, 1992: 274)
} 
treatment is lasting too long and is too expensive. After 1952 APA has in more occasions, revised Manuel in a sense of radical abandoning synthesis that a dynamic psychiatric has performed. Copied from the scheme sign-diagnosis-treatment, at the end, it has also excluded from its classification subjectivity itself. There had been made 4 versions: 1968 (DSM II9), 1980 (DSM III), 1987 (DSM III-R) and 1994 (DSM -IV). The result of gradual, so called "a-theoretic" operation of cleaning, according to Roudinesco, was catastrophic. That operation was going for a detailed presentation how a disorder in a soul must be brought to the equivalent of the engine dysfunction. From this starts the removing of all terminology that was made by psychiatric and psychoanalysis. Terms (psychosis, neurosis, perversion) are replaced by unclear term "disorder" (disorder $=$ desordre $=$ mess), and clinical entities are abandoned for the benefit of symptomatic characterisation of those known messes (2005: 36, 37, 38).

The author states that only psychoanalysis was able, from the beginning to execute synthesis of four big models of dynamic psychiatry necessary for rational understanding of craziness and psychic illness. It has borrowed from the psychiatry its nosographic model, from psychotherapy model of psychiatric treatment, from philosophy theory of subject and from anthropology concept of culture based on the idea of humankind universality, which is full of respect for differences. Unless it wants to embarrass itself, it cannot as such contribute today the dominant idea about psychic organisation being brought down to behaviour. Hence Roudinesco will, like Winnicott, conclude how subjectivity isn't measurable or quantifiable: it is the experiment, at the same time visible and invisible, unconscious or conscious with which is being confirmed the essence of human experience (2005: 40).

Hence, it is clear that in these constellations there is little space and time for a doll. And so, in some way it is neglected the deepest aspect of a doll - its influence on people's lives. In that, at first sight, a little, but crucial segment, pedagogues, psychologists, psychiatrists and puppeteers meet. Polish puppeteer Wieslaw Hejno describes dolls as human-looking objects that can keep somewhat undiscovered secret, certainly not the secret of life, but can point to the way towards the spring of realisation. For him, a doll is something liberated from the fear of dying, indifferent to insults and discomforts, liberated from feelings of tension, in general insensitive, non-thinkable and not alive, which is paradoxical I - a figure that I can bring to life and fill with all what is missing, but anticipates me. Therefore, the puppeteer, as well as a doctor for soul, can with a doll make impression as a man, ripped out from life, floats in space, powerless to reach its own person that is running in front of him with parallel belief how he is holding it in hands, which makes him calmer and offers a sense of security (2002: 262, 264).

In the context of general non-subjectivity, Hejno, like Roudinseco and Winnicott, envisions the next generations how indifferently pass next to dolls or maybe reverse, dolls will stay the only testimony of humanity, because in the world, a living being, is not capable to make its own doll. 
In the end, it seems extremely important to notice, how a graduating student of preschool teaching, a co-author of this essay ${ }^{11}$, has by watching TV, on a gloomy evening, seen a man, a veteran of The War of Independence, who was sharing his unusual experience of psychic healing by holding a doll in his hand, making and revealing talisman's numen of a doll. With that life fact, this essay ends, and with the very same fact must start a true search for human in this world.

\section{Bibliography}

\section{Books}

Bastašić, Zlatko: Lutka ima i srce i pamet, ŠK, Zagreb, 1988.

Bettelheim, Bruno: The Uses of Enchantment: The Meaning and Importance of Fairy Tales, transl. by Vladimir Jakić, Poduzetništvo Jakić, Cres, 2000.

Estes, Clarisa Pinkola: Women Who Run With the Wolves: Myths and Stories of the Wild Woman Archetype, transl. Lara Hoelbling Matković, Algoritam, Zagreb, 2004.

Freud, Anna: Einfuehrung in die Technik der Kinderanalyse, transl. Nikola Prodanović, Naklada Slap, Jastrebarsko, 2002.

Freud, Sigmund: 1. Selbstdarstellung ; 2. Neue Folge der Vorlesungen zur Einfuehrung in die Psychoanalyse, transl. Vladeta Jerotić, Nikola Volf, Matica Srpska, Novi Sad, 1979.

Gruden, Zdenka: Dječja psihoterapija, Medicinska naklada, Zagreb, 1996.

Hejno, Wieslaw: Lalkarz, transl. Pero Mioč, NZMH, Zagreb, 2002.

Klein, Melanie: The phsycho-analysis of children; Love, guilt and reparation and other works; Envy and gratitude and other works, transl. Anita Sujoldžić, Naprijed, Zagreb, 1983.

Mejerholjd, Vsevolod E.: Stat'i, pis'ma, reči, besedy, Nolit, Beograd, 1976.

Nussbaum, Martha, C.: Poetic justice, transl. Marina Miladinov, Deltakont, Zagreb, 2005.

Pokrivka, Vlasta: Dijete i scenska lutka, ŠK, Zagreb, 1985.

Roudinesco, Elizabeth: Pourquoi la psychanalyse?, transl. Marina Bonačić-Kapor, Naklada Slap, Jastrebarsko, 2005. 1980.

Winnicott, Donald Woods: The Child, the Family, and the Outside World, Naprijed, Zagreb,

Winnicott, Donald Woods: The Piggle; An Account of the Psychoanalytic Treatment of a Little Girl, Prosvjeta, Zagreb, 1997.

Winnicott, Donald Woods: Playing and Reality, Prosvjeta, Zagreb, 2004.

\section{Chapters is books}

Felman, Shoshana: Beyond Oedipus: The specimen Story of Psychoanalysis, transl. 258.- 310 .

Andrea Zlatar in Suvremena teorija pripovijedanja, Vladimir Biti, globus, Zagreb, 1992, page

${ }^{11}$ Karmen Vidović, A child and a doll, graduation thesis, see Conclusion, Higher teachertraining school in Pula, 2006. 


\section{Periodicals}

Hicela, Ivon, „Utjecaj odgojiteljeve interakcije s lutkom na dječju spontanu igru“, Školski vjesnik, 55, 2006, No. 1-2, pages 11-21

Vidić, Vedrana, „Lutka u odgojno-obrazovnom radu u dječjem vrtiću“, Školski vjesnik, 55, 2006, No. 1-2, pages 23-29

Metodički obzori 9, vol. 5(2010)1

Pregledni rad

UDK: $159.922 .7 / 8: 792.97$

Primljeno: 21. 10. 2009.

\section{DIJETE I PSIHIČKI ASPEKTI LUTKE \\ (Teorijski pristup)}

Dr. sc. Jasna Gržinić,

Sveučilište Jurja Dobrile u Puli, Odjel za obrazovanje učitelja i odgojitelja e-mail: jasna_grzinic@inet.hr

Saša Ilić, diplomantica Sveučilište Jurja Dobrile u Puli, Odjel za obrazovanje učitelja i odgojitelja

Karmen Vidović, diplomantica Sveučilište Jurja Dobrile u Puli, Odjel za obrazovanje učitelja i odgojitelja e-mail: karmen_vidovic@net.hr

\section{Sažetak}

$\mathrm{U}$ radu se traga za izgubljenim značenjem lutke u kontekstu užurbanog i košmarnog svijeta koji zastupaju zakoni ekonomske dobiti. U tom se smislu preispituju dosezi filozofije, psihologije, psihoanalize, pedagogije i književnosti. Oni upućuju na potrebu sinkretičkog promišljanja svijeta i važnost njegovanja lutke i lutkarskoga umijeća.

Ključne riječi: lutka, psihoanaliza, igra, terapija, odgoj 